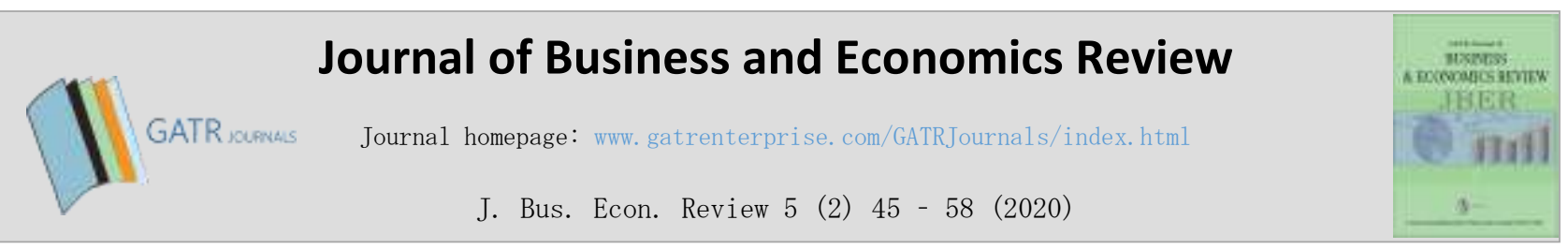

\title{
Public Expenditure and Economic Growth in India: An Empirical Analysis Using Vector Autoregression (VAR) Model
}

\author{
Rashmi Gupta, ${ }^{1}$ Swati Shastri ${ }^{2}$ \\ ${ }^{1}$ Assistant Professor, Economics, (GES-II) Department Of Higher Education, Government of Gujarat, Ahmedabad, Gujarat India \\ ${ }^{2}$ Associate Professor, Department Of Economics, Banasthali University, Dist.-Tonk, Rajasthan India
}

\begin{abstract}
Objective - The objective of this study is to test direction of causality between components of public expenditure and economic growth in India.

Methodology/Technique - The paper uses annual data for the period 1980-2015. To measure public expenditure, plan expenditure and non-plan expenditure are used. The econometric methodology employed is Vector Auto regression (VAR) model.

Findings - First, the stationary properties of the data were tested using Augmented Dickey-Fuller (ADF) test, DickeyFuller (DF) test, and the Phillip-Perron (PP) test and found that variables were non-stationary in level, but stationary in first differences. Then, Johansen- Jueslius cointegration test was employed to test the long-run association among the variables and results suggest an absence of any long-run association between plan expenditure and non-plan expenditure and economic growth in India. The Granger Causality test suggests there is unidirectional causality running from economic growth and non-plan expenditure and plan expenditure and non-plan expenditure and absence of causality public expenditure and economic growth.

Novelty - The results of the Forecast Error Variance Decompositions test indicated that innovations in the variables are mostly explained by their own shocks. The impulse responses of the economic growth, plan expenditure and non-plan expenditure with respect to identified shocks are consistent with the results of Variance Decomposition Analysis.

Type of Paper: Empirical.

JEL Classification: O4, O49, O53.
\end{abstract}

Keywords: Plan Expenditure; Non-plan Expenditure; Economic Growth; Unit Root; Cointegration Test; Granger Causality Test; Forecast Error Variance Decomposition; Impulse Responses.

Reference to this paper should be made as follows: Gupta, R; Shastri, S. (2020). Public Expenditure and Economic Growth in India: An Empirical Analysis Using Vector Autoregression (VAR) Model, J. Bus. Econ. Review, 5(2) 45- 58 https://doi.org/10.35609/jber.2020.5.2(1)

\section{Introduction}

Fiscal policy is the key ingredient for the growth of any economy. The prime objective of fiscal policy is to accelerate economic growth through the mechanism of revenue and expenditure in a country.

\footnotetext{
* Paper Info: Revised: July 12, 2020

Accepted: September 30, 2020

* Corresponding author: Rashmi Gupta

E-mail: rashmi_gupta2021@yahoo.com

Affiliation: Department Of Higher Education, Government of Gujarat, Ahmedabad, Gujarat India
} 
According to the World Bank "Public or government expenditure is the expenditure of public authority central, state and local governments." This spending is made to protect the people and to improve their wellbeing through productive activities. Economic growth can be stated as the increase in the amount of the goods and services produced by an economy over time. It is conventionally measured as the percentage of increase in real GDP. The change in value of goods and services produced in an economy is the mirror of economic growth in that economy.

In this paper, the relationship between plan expenditure, non-plan expenditure and economic growth in India is discussed. A five-year plan model has been the main pillar of the development strategy in the Indian Economy. Twelve five-year plans were designed from 1951-2017 to implement developmental strategies. Thus, expenditure during planning period may have a positive and significant contribution in economic growth hence it is important to discuss the relationship between public expenditure and economic growth.

Plan Expenditure can be explained as part of budgetary expenditure which is meant for finance the schemes and programs framed under annual and five years plan and financed by the government on the recommendations of the planning commission. Plan expenditure occurs mainly in the creation of assets. The expenditure related to new projects and programs becomes plan expenditure during the period of a five-year plan. Major heads of the plan expenditure may vary in each five-year plan which depends upon the objectives of that respective plan. Agriculture and Allied Activities, Rural Development, Irrigation and Flood Control, Energy, Industry and Minerals etc. are some heads of plan expenditure in India.

Non-plan Expenditure includes that expenditure which is recommended by the finance commission when it makes recommendations regarding allocation of resources from the Central Government to the States. It is a committed expenditure on maintaining the assets created in previous plans and on the recurring parts of plan expenditure on different programs or schemes. Interest Payments and Debt Servicing, Defense, Subsidies, Assistance to States from National Calamity Contingency Fund/National Disaster Response Fund (NDRF), General Elections, Postal Deficit, reimbursement of losses to Railways on operating Strategic Railway Lines, Subsidy to Railways towards dividend reliefs and other concessions etc. are some major heads of Non-plan Expenditure in India. Interest payments, defense expenditures, subsidies and general services, together form more than $90 \%$ of Non-plan Expenditures.

To study the relationship between classified/disaggregated public expenditure and economic growth is more desirable because it suggests targeted policy decisions. The classification of government expenditure is important for policy formulation and decision-making on allocation of financial resources, monitoring of performance of various government programs and activities, establishment of accountability for budgetary commitments, and in the analysis of overall economic impact of government policies. And each classification of government expenditure is closely related to the objectives of the government economic growth, financial control, price stability etc.

The major objective of this study is to examine the direction of the causality between government plan and non-plan expenditure and economic growth in India. The answer to the question of whether increasing government expenditures are the cause of economic growth or economic growth is the cause of increasing government expenditures is particularly important for India where the public sector has a relatively large share of the economy's resources during the planning period.

\section{Review of Existing Literature}

In theoretical literature, there are 2 opposing approaches on the relationship between government expenditure and economic growth which has been the subject of great interest of economists for empirical testing. The first approach is Wagner's hypothesis which states that public expenditure is an endogenous variable or an outcome and function of GDP. On the contrary, Keynesian view states public expenditure is an exogenous variable that effects the level of GDP in an economy and can also be used as a policy instrument.

J. Bus. Econ. Review 5 (2) 45 - 58 (2020) 
Consequently, he believes that the causality of the relationship between public expenditure and economic growth runs from expenditure to growth.

To study the empirical relationship between economic growth and government expenditure, researchers took great interest in both developed and developing economies. Among the earlier empirical analysis, assuming stationary data, research carried out by Musgrave (1969), Michas (1975), Mann (1980), Ram $(1986,1987)$ concludes in favor of Wagner's hypothesis. In the case of developing economies, studies by Gandhi (1971) and Ram (1987) do not support Wagner's Law. However, because of the serious shortcomings of these studies, modern techniques have been developed and the use of new techniques has produced mixed results. Barro (1990) concludes that public expenditure on investment and on productive activities is supposed to effect economic growth positively, but government consumption expenditure is anticipated to be growth retarding.

Donald and Shuanglin (1993) investigate the impact of a disaggregated form of public expenditure on economic growth for 58 sampled economies and conclude that expenditure on defense and education has a positive effect on economic growth but a negative and insignificant effect on welfare. In Pakistan's economy, Jamshed, Iqbal and Siddiqi (2010) examine the nature and the direction of causality between public expenditure and national income alongside various selected components of public expenditure, development expenditures, administration expenditures, debt services, defense services, applying the Toda-Yamamoto causality test for annual data within the period of 1971-2006. The study concludes that there is a unidirectional causality running from GDP to government expenditure, which supports Wagner's Law.

At a disaggregated level, results show that GDP only causes administrative expenditure while no causality was found on development expenditures, debt servicing and defense expenditures. Akpan (2005) and Loto (2011) studied the link between public expenditure and economic growth and reveal that economic growth and most components of government expenditure are not significantly linked in Nigeria. Komain and Brahmasrene (2007) investigate the relationship between these 2 variables in Thailand, using the Granger causality test and acknowledged the existence of unidirectional causality which runs from government expenditures to growth and found significant and positive effect of public expenditure on growth. Liu et. al. (2008) studied the nature of the relationship between public expenditure and GDP for the US economy during the period 1947-2002.

The econometric results indicate that public expenditure increases economic growth. Judging from the causality test, the study concludes that Keynesian's hypothesis has more influence than Wagner's law in the US. Abizadeh and Yousefi (1998) use South Korean data to test Wagner's law. They first conduct Granger type causality tests, and then estimate a growth equation and a government expenditure growth equation by using annual data for the period of 1961-1992. They exclude government expenditures from the GDP to obtain the private sector GDP and use this in their tests. After comparing the results from the estimations, the authors conclude that government expenditures did not contributed to economic growth in Korea.

Homnath Gaire (2013) examines the relevance of Keynesian postulates in the Nepalese context for the period 1975-2012 using annual time series data. The empirical result from the Johansen co-integration tests clearly show that there is long-run equilibrium relationship between government expenditure and real GDP, private consumption and gross fixed capital formation. The Granger causality test also confirms that there is a bilateral causal relationship between government expenditure and gross fixed capital formation in Nepal. However, no causal relationship is observed between government expenditure and real GDP and private consumption. observed, that is, from national income growth to government expenditure growth.

Thus, Islam (2001) uses annual data for the period 1929-1996 to examine the Wagner's hypothesis for the US. That study found that the relative size of government expenditure and real Gross National Product per capita are cointegrated by using the Johansen-Juselius cointegration approach. Moreover, Wagner's hypothesis is strongly supported by the results of Engle-Granger (1987) in error correction approach. 
However, there are few of such studies in the context of the Indian Economy and the findings of these studies are conflicting and contradict each other. Verma and Arora (2010) and Ray and Ray (2012) also confirm the absence of any immediate impact of increasing GDP and the size of government expenditure in India as well as the presence of causality between economic growth and government expenditure which neither supports Wagner's law nor Keynesian's approach In India. On the contrary, Sakthivel and Yadav (2005) and Sayed (2012) identified the existence of bi-directional causality between these two. Acharya (2012) studied the empirical validity of Wagner law in SAARC countries during 1995-2008 and concluded that Wagner's law is applicable to India, Bhutan, Nepal, Pakistan and Sri Lanka but not to Bangladesh.

\section{Data and Methodology}

This paper covers a period of 35 years from 1980-2015. The analysis is based on secondary data. To measure economic growth, log of real GDP (LRGDP) is used. To measure public expenditure at a disaggregated level, log of real plan expenditure (LRPE) and log of real non-plan expenditure (LRNPE) are used. During the study period (1980-2015) we had different base years, so to avoid misleading and spurious results, all data has been rebased to current base year 2011-12. The main sources of secondary data are budget documents of the central government and Indian Public Finance Statistics.

To examine the direction of causality between components of government expenditure and economic growth, this paper has employed the Vector Autoregression (VAR) methodology and this econometric test is preceded with the stationarity and cointegration test on the variables employed in the study.

\subsection{Unit Root Test}

The start point in the causality test is to determine the order of integration of each variable. It is well known that when dealing with time series data, stationarity tests are used to avoid the problem of spurious regression (Engle \& Granger, 1987). A Unit Root test is conducted to test the stationarity of the variables. This is done by 3 main tests of stationarity using Augmented Dickey-Fuller test (ADF test), Dickey Fuller Test (DF test) and Phillip Perron Test (PP test). All 3 tests are carried out to test stationarity without trend but with intercept and with trend and intercept both. The unit root test has estimated by using following regressions:

$$
\begin{aligned}
& \Delta \mathrm{Y}_{\mathrm{t}}=\beta+\delta \mathrm{Y}_{\mathrm{t}-1}+\alpha_{\mathrm{i}} \sum_{\mathrm{i}=0}^{\mathrm{m}} \Delta \mathrm{Y}_{\mathrm{t}-1}+\epsilon_{\mathrm{t}} \\
& \Delta \mathrm{Y}_{\mathrm{t}}=\beta+\beta_{2} \mathrm{~T}+\delta \mathrm{Y}_{\mathrm{t}-1}+\alpha_{\mathrm{i}} \sum_{\mathrm{i}=0}^{\mathrm{m}} \Delta \mathrm{Y}_{\mathrm{t}-1}+\epsilon_{\mathrm{t}}
\end{aligned}
$$

Where $€ \mathrm{t}$ is pure white noise error term, $\mathrm{m}$ is lag, $\beta$ is constant and where $\Delta \mathrm{Yt}-1=(\mathrm{Yt}-1-\mathrm{Yt}-2), \Delta \mathrm{Yt}-2=$ (Yt-2- Yt-3), and so on. And The hypothesis to test stationarity is:

H0: $\delta=0$ (unit root)

H1: $\delta \neq 0$ (unit root does not exist)

Decision Rule:

If $\mathrm{t}>\mathrm{ADF}$ critical values, then not reject null hypothesis (unit root exists)

If $\mathrm{t}<\mathrm{ADF}$ critical values, then reject null hypothesis (unit root does not exist). 


\subsection{Cointegration Test}

Two or more variables are said to be cointegrated if they share a common trend or we can say the series are linked by some long-run equilibrium relationship from which they can deviate in the short-run but they must return to it in long-run. If two variables X and Y I (1) then the next step to find out they have cointegration. To determine the number of co-integration vectors, Johansen $(1988,1989)$ and Johansen and Juselius (1990) suggest 2 statistic tests, the first is the trace test and the Second is the maximum eigenvalue test. These tests are calculated as follows:

$$
\begin{aligned}
& Y_{t}=\alpha+\beta X_{t}+U_{t} \\
& X_{t}=\alpha+\beta X_{t}+U_{t t}
\end{aligned}
$$

Two series Yt and Xt are cointegrated if both series are integrated of say I (1) and the residuals from the cointegrating equation ut and utt should be I (0).

\subsection{Granger Causality Test}

Once cointegration is established, the causality relationship between 2 variables is to be established using Granger's test of causality. Granger (1969) argues that a variable X is said to cause another variable Y, if current $\mathrm{Y}$ can be predicted better by using past values of $\mathrm{X}$ than by not doing so. The causality relationship can be evaluated by estimating the following two regression equations:

$$
\begin{aligned}
& \mathrm{Y}_{\mathrm{t}}=\mathrm{C}_{0}+\sum_{\mathrm{i}=0}^{\mathrm{r}} \mathrm{C}_{\mathrm{i}} \mathrm{Y}_{\mathrm{t}-\mathrm{i}}+\sum_{\mathrm{j}=0}^{\mathrm{s}} \mathrm{d}_{\mathrm{i}} \mathrm{X}_{\mathrm{j}-\mathrm{i}}+\mathrm{V}_{\mathrm{t}} \\
& \mathrm{Y}_{\mathrm{t}}=\mathrm{C}_{0}+\sum_{\mathrm{i}=1}^{\mathrm{r}} \mathrm{C}_{\mathrm{i}} \mathrm{Y}_{\mathrm{t}-\mathrm{i}}+\mathrm{V}_{\mathrm{t}} \\
& \mathrm{X}_{\mathrm{t}}=\mathrm{a}_{0}+\sum_{\mathrm{i}=1}^{\mathrm{p}} \mathrm{a}_{\mathrm{i}} \mathrm{X}_{\mathrm{t}-\mathrm{i}}+\sum_{\mathrm{j}=1}^{\mathrm{q}} \mathrm{b}_{\mathrm{j}} \mathrm{Y}_{\mathrm{t}-\mathrm{j}}+\mathrm{W}_{\mathrm{t}} \\
& \mathrm{X}_{\mathrm{t}}=\mathrm{a}_{0}+\sum_{\mathrm{i}=1}^{\mathrm{p}} \mathrm{a}_{\mathrm{i}} \mathrm{X}_{\mathrm{t}-\mathrm{i}}+\mathrm{W}_{\mathrm{t}}
\end{aligned}
$$

Where Xt and Yt are stationary time series, and Wt and Vt are uncorrelated white noise series. The causality test to be performed can be stated as:

i) $\mathrm{X}$ causes $\mathrm{Y}$ if $\mathrm{HO}: \Sigma \mathrm{dj}=0, \mathrm{j}=1 \ldots . . \mathrm{s}$ can be rejected

ii) $Y$ causes $X$ if $\mathrm{HO}: \Sigma b j=0, j=1 \ldots \ldots q$ can be rejected

iii) Bi-directional causality is if both (i) and (ii) hold.

iv) Independent if both (i) and (ii) do not hold.

Following this approach, the null hypothesis (i) and (ii) that is $\Sigma \mathrm{dj}=0$ and $\Sigma \mathrm{bj}=0$ can be tested by through the implementation of F-test follows F distribution with $n$ and $T-(m+n+1)$ degrees of freedom. Where:

$\mathrm{n}=$ number of lagged terms of independent variable

$\mathrm{m}=$ number of lagged terms of dependent variable

$\mathrm{T}=$ number of observations. 
The Granger Causality test is sensitive to choice of lag length. This has been done using model selection criterion such as the Akaike Information Criterion (AIC) and Schwarz Bayesian Criterion (SBC).

\section{Empirical Analysis}

\subsection{Unit Root Test}

This involves testing for the stationarity of the individual variables using the Augmented Dickey Fuller (ADF), Dickey Fuller (DF) and Phillips-Perron (PP) tests to identify the existence of unit root in each of the time series. The results of the ADF, DF and PP tests are reported in tables below:

Table 1.4.1.1 ADF, DF and PP Stationarity test at Levels

\begin{tabular}{|c|c|c|c|c|c|c|}
\hline Variables & $\begin{array}{c}\text { ADF (Inter- } \\
\text { cept) }\end{array}$ & $\begin{array}{c}\text { ADF (Intercept } \\
\text { and Trend) }\end{array}$ & DF (Inter-cept) & $\begin{array}{c}\text { DF (Intercept } \\
\text { and Trend) }\end{array}$ & $\begin{array}{c}\text { PP } \\
\text { (Inter- } \\
\text { cept) }\end{array}$ & $\begin{array}{c}\text { PP } \\
\text { (Intercept } \\
\text { and Trends) }\end{array}$ \\
\hline LRGDP & $2.8(3.6)^{*}$ & $1.48(3.5) * *$ & $0.52(2.6)^{*}$ & $0.95(3.1) * *$ & 3.4 & 1.29 \\
\hline LRPE & $0.29(3.6)^{*}$ & $1.35(3.5) * *$ & $1.01(2.6) *$ & $1.3(3.1)^{* *}$ & 0.47 & 1.4 \\
\hline LRNPE & $1.56(3.6)^{*}$ & $5.7(3.5) * *$ & $0.93(2.6) *$ & $5.7(3.1)^{* *}$ & 2.2 & 5.8 \\
\hline
\end{tabular}

Source: computed by author by using EViews software

Note: $*$ and $* *$ denotes Significance at $1 \%$ level and 5\% level and figures within parenthesis indicate critical values respectively. Mackinnon (1991) critical value for rejection of hypothesis of unit root applied.

Table 1.4.1.1 above shows that all the variables were not stationary in levels. This can be seen by comparison of observed values of the ADF, DF and PP test statistics with the critical values of the test statistics at the $1 \%$ and 5\% level of significance. The results from that table provide strong evidence of nonstationarity because the calculated statistics are less than the test statistics. Therefore, the null hypothesis is accepted and it is sufficient to conclude that there is a presence of unit root in the variables at all levels.

1.4.1.2 ADF, DF and PP Stationarity test at First Difference

\begin{tabular}{|c|c|c|c|c|c|c|}
\hline Variables & $\begin{array}{c}\text { ADF (Inter- } \\
\text { cept) }\end{array}$ & $\begin{array}{c}\text { ADF (Intercept } \\
\text { and Trend) }\end{array}$ & DF (Inter-cept) & $\begin{array}{c}\text { DF (Intercept } \\
\text { and Trend) }\end{array}$ & $\begin{array}{c}\text { PP } \\
\text { (Inter- } \\
\text { cept) }\end{array}$ & $\begin{array}{c}\text { PP } \\
\text { (Intercept } \\
\text { and } \\
\text { Trends) }\end{array}$ \\
\hline LRGDP & $3.8(3.6)^{*}$ & $4.5(3.5)^{* *}$ & $3.8(2.6)^{*}$ & $4.5(3.1)^{* *}$ & 3.7 & 4.9 \\
\hline LRPE & $7.0(3.6)^{*}$ & $7.1(3.5)^{* *}$ & $7.1(2.6)^{*}$ & $7.29(3.1)^{* *}$ & 6.9 & 7.0 \\
\hline LRNPE & $10.1(3.6)^{*}$ & $10.0(3.5)^{* *}$ & $10.2(2.6)^{*}$ & $10.3(3.1)^{* *}$ & 22.3 & 21.6 \\
\hline
\end{tabular}

Source: computed by author using EViews software 11

Note: * and ** denotes Significance at $1 \%$ \& 5\% level, respectively and figures within parenthesis indicate critical values. Mackinnon (1991) critical value for rejection of hypothesis of unit root applied.

Table 1.4.1.2 above reveals that all of the variables were stationary at first difference, meaning that the null hypothesis of non-stationary is rejected because the critical values are greater than the test values and it is convincing to accept that the variables are stationary. This implies that the variables are integrated of order one, i.e. 1(1). 


\subsection{Selection of Lag Length}

Before examining the long-run association, there is a need to determine the optimum lag-length of the model. For this purpose, a VAR test is applied and lag length is selected on the basis of both Akaike Information Criterion (AIC) and Schwarz Information Criterion (SIC). As per the guidelines of these 2 criteria, the lower the AIC and SIC are better the model. The table used to select lag length is shown below:

Table 1.4.2.1 selection of leg length

\begin{tabular}{|c|c|c|c|c|c|c|}
\hline Lag & Logl & $\mathbf{L R}$ & FPE & AIC & SC & HQ \\
\hline 0 & -32.07895 & NA & 0.001682 & 2.125997 & 2.262043 & 2.171772 \\
\hline 1 & 107.0329 & $244.4997 *$ & $6.35 \mathrm{e}-07 *$ & $-5.759572 *$ & $-5.215387 *$ & $-5.576470 *$ \\
\hline 2 & 115.2242 & 12.90740 & $6.78 \mathrm{e}-07$ & -5.710556 & -4.758233 & -5.390128 \\
\hline 3 & 121.1076 & 8.201104 & $8.51 \mathrm{e}-07$ & -5.521671 & -4.161210 & -5.063917 \\
\hline \multicolumn{6}{|c|}{$*$ indicates lag order selected by the criterion } & \\
\hline \multicolumn{7}{|c|}{ LR: sequential modified LR test statistic (each test at 5\% level) } \\
\hline \multicolumn{7}{|c|}{ FPE: Final prediction error } \\
\hline \multicolumn{7}{|c|}{ AIC: Akaike information criterion } \\
\hline \multicolumn{7}{|c|}{ SC: Schwarz information criterion } \\
\hline \multicolumn{7}{|c|}{ HQ: Hannan-Quinn information criterion } \\
\hline
\end{tabular}

Source: computed by author by using EViews software

Table 1.4.2.1 shows the lag orders which are selected by the criterion. According to the guidelines of the model, lag of 2 year is the optimal lag length.

\subsection{Cointegration Test Analysis}

The results of the cointegration test are discussed in Table 1.4.3.1 below.

Table 1.4.3.1: Part 1: Trace Statistics

\begin{tabular}{|c|c|c|c|c|}
\hline Null hypothesis & $\begin{array}{l}\text { Alternative } \\
\text { Hypothesis }\end{array}$ & Test Statistics & Critical Value & Probability \\
\hline Ho $: r<=0$ & HA $: r>0$ & 26.45628 & 29.79707 & 0.1156 \\
\hline Ho $: r<=1$ & HA $: r>1$ & 10.84351 & 15.49471 & 0.2213 \\
\hline Ho $: r<=2$ & HA $: r>2$ & 2.697625 & 3.841465 & 0.1005 \\
\hline
\end{tabular}

Source: computed by author using EViews 11 software

Table 1.4.3.1: Part 2: Max-Eigen value

\begin{tabular}{|c|c|c|c|c|}
\hline Null hypothesis & $\begin{array}{l}\text { Alternative } \\
\text { Hypothesis }\end{array}$ & Test Statistics & Critical Value & Probability \\
\hline Ho $: r<=0$ & HA $: r>0$ & 15.61277 & 21.13162 & 0.2483 \\
\hline Ho $: r<=1$ & HA $: r>1$ & 8.145882 & 14.26460 & 0.3641 \\
\hline Ho $: r<=2$ & HA $: r>2$ & 2.697625 & 3.841465 & 0.1005 \\
\hline
\end{tabular}

Source: computed by author using EViews 11 software 
It may be seen in the part I and part II of Table 1.4.3.1 that the results of the Trace statistics and MaxEigen statistics reveals that in the case of all null hypothesis, the Trace and Max-Eigen statistics are less than the critical values and the p-value is also greater than 5\%, which means that we cannot reject all of the null hypothesis that there is no cointegration between variables (i.e. alternative hypothesis is accepted which means there is existence of co integration). The cointegration test suggests the absence of a long-run relationship between public expenditure and economic growth.

\subsection{Vector Auto Regression (VAR) Model}

The VAR model is used to determine the relationship among several variables. For the analysis of data time series which involve more than one variable the Vector Autoregressive (VAR) is used. The 3 techniques needed for using the VAR model in analysis are the Granger causality test, impulse-response analysis, and the variance decomposition method.

After the prediction of the VAR model, the test should be made on error term and the predicted VAR model should be tested to see whether its structure is stable. Hence, before conducting the causality test, the Variance decomposition and Impulse Response Function, we need to determine that values of autocorrelation, heteroscedasticity and normality are within the desirable limits.

Table 1.4.4.1 Statistical Summary of VAR Model (LRGDP) as dependent variable)

\begin{tabular}{|c|c|}
\hline Test Name & p Value \\
\hline Serial Correlation & 0.076 \\
\hline Heteroscedasticity & 0.645 \\
\hline Histogram Normality & 0.316 \\
\hline
\end{tabular}

Source: computed by author by using EViews software

Table 1.4.4.1 shows that in first VAR model (GDP expenditure is dependent) serial correlation and heteroscedasticity is absent (i.e. p-value of observed X2is greater than 5\%) and the data is also normally distributed because the probability is more than $5 \%$, which is desirable.

Table 1.4.4.2 Statistical Summary of VAR Model (LRPE as dependent variable)

\begin{tabular}{|c|c|}
\hline Test Name & p Value \\
\hline Serial Correlation & 0.265 \\
\hline Heteroscedasticity & 0.626 \\
\hline Histogram Normality & 0.773 \\
\hline
\end{tabular}

Source: computed by author by using EViews software

Table 1.4.4.2 shows that in second VAR model (plan expenditure as dependent variable), serial correlation and heteroscedasticity is absent which is desirable (i.e. p-value of observed X2is greater than 5\%) and the data is also normally distributed.

Table 1.4.4.3 Statistical Summary of VAR Model (LRNPE as dependent variable)

\begin{tabular}{|c|c|}
\hline Test Name & p Value \\
\hline Serial Correlation & 0.264 \\
\hline Heteroscedasticity & 0.138 \\
\hline
\end{tabular}




\begin{tabular}{|c|c|}
\hline Histogram Normality & 0.000 \\
\hline \multicolumn{2}{|c|}{ Source: computed by author by using EViews software } \\
\hline
\end{tabular}

Source: computed by author by using EViews software

Table 1.4.4.3 shows that in thethird VAR model (non-plan expenditure is dependent) serial correlation and heteroscedasticity is absent which is desirable and but the data is not normally distributed because the Jarquebera probability is less than $5 \%$, which is not desirable.

Table 1.4.4.4 Granger Causality Test Results:

\begin{tabular}{|c|c|c|c|}
\hline Null Hypothesis & F-Stat & Prob & Decision \\
\hline Non-plan Exp does not Granger cause GDP & 0.91298 & 0.4126 & Accept \\
\hline GDP does not Granger cause Non-plan exp & 7.22479 & 0.0028 & Reject \\
\hline Plan exp does not Granger cause GDP & 0.05596 & 0.9457 & Accept \\
\hline GDP does not Granger cause plan exp & 1.11877 & 0.3404 & Accept \\
\hline Plan exp does not Granger Cause Non-plan exp & 9.17196 & 0.0008 & Reject \\
\hline Non-plan exp does not Granger cause plan exp & 0.19770 & 0.8217 & Accept \\
\hline
\end{tabular}

Source: computed by author by using EViews software

Table 1.4.4.4 shows that there is short-run unidirectional causal relationship running from GDP to nonplan expenditure and plan expenditure to non-plan expenditure. Further, the $\mathrm{p}$ Values of the remaining variables are greater than ( $p>0.5 \%$ ), which means there is no causality between GDP and plan expenditure, non-pan expenditure to GDP and non-plan to plan expenditure in India during 1980-2015.

\subsubsection{Forecast Error Variance Decomposition}

Table 1.4.4.5.I Variance decomposition of $\log$ of real gross domestic product

\begin{tabular}{|c|c|c|c|c|}
\hline Period & S.E. & LRGDP & LRPE & LRNPE \\
\hline 1 & 0.017042 & 100.0000 & 0.000000 & 0.000000 \\
\hline 2 & 0.026607 & 99.51216 & 0.110057 & 0.377779 \\
\hline 3 & 0.034441 & 96.93154 & 0.600743 & 2.467719 \\
\hline 4 & 0.040811 & 94.84552 & 1.464297 & 3.690187 \\
\hline 5 & 0.046308 & 93.76122 & 1.781608 & 4.457176 \\
\hline 6 & 0.051310 & 93.18892 & 1.915499 & 4.895580 \\
\hline 7 & 0.055987 & 92.89051 & 1.926339 & 5.183147 \\
\hline 8 & 0.060434 & 92.71680 & 1.892109 & 5.391094 \\
\hline 9 & 0.064698 & 92.61199 & 1.836431 & 5.551580 \\
\hline 10 & 0.068815 & 92.54892 & 1.771370 & 5.679710 \\
\hline
\end{tabular}

Source: computed by author using EViews software

An examination of the variance decomposition of LRGDP in table 1.4.4.5.I shows that a substantial amount of the variation experienced by LRGDP is attributed to its own shock (100\%) in the first period, but the shock fades out gradually to about $92.54 \%$ at the end of the horizon. The contribution of Plan Expenditure marginally follows an increasing trend from the first to the seventh period, but decreases until the end of the horizon where it stood at $1.77 \%$. Meanwhile, LRNPE marginally follows an increasing trend and stood at $5.67 \%$ until the end of the horizon. 
Table no. 1.4.4.5.II Variance decomposition of log of real Plan Expenditure

\begin{tabular}{|c|c|c|c|c|}
\hline Period & S.E. & LRGDP & LRPE & LRNPE \\
\hline 1 & 0.103914 & 0.263399 & 99.73660 & 0.000000 \\
\hline 2 & 0.125638 & 0.187026 & 99.70404 & 0.108930 \\
\hline 3 & 0.143779 & 0.184484 & 99.61849 & 0.197029 \\
\hline 4 & 0.156066 & 0.227578 & 99.55104 & 0.221385 \\
\hline 5 & 0.165085 & 0.346681 & 99.40025 & 0.253066 \\
\hline 6 & 0.172035 & 0.532441 & 99.18308 & 0.284481 \\
\hline 7 & 0.177461 & 0.785104 & 98.89259 & 0.322311 \\
\hline 8 & 0.181813 & 1.101964 & 98.53391 & 0.364128 \\
\hline 9 & 0.185356 & 1.482273 & 98.10801 & 0.409715 \\
\hline 10 & 0.188301 & 1.925113 & 97.61636 & 0.458531 \\
\hline
\end{tabular}

Source: Computed by author using EViews software

The variance decomposition is shown in Table 1.4.4.5.II about LRPE variable. In the short-run shock to plan expenditure accounts for $99.73 \%$ variation of fluctuation in plan expenditure (own shock) in first year and this rate decreases at the end of the 10th period to $97.61 \%$. While the shock to GDP and non-plan expenditure account for $0.26 \%$ and $0 \%$ variations respectively, in fluctuation in plan expenditure in first year. And this rate increases at the end of the 10 th period to $1.92 \%$ and $0.45 \%$ respectively.

Table 1.4.4.5.III Variance decomposition of log of real Non- Plan Expenditure

\begin{tabular}{|c|c|c|c|c|}
\hline Period & S.E. & LRGDP & LRPE & LRNPE \\
\hline 1 & 0.360445 & 0.316369 & 1.996352 & 97.68728 \\
\hline 2 & 0.403102 & 4.773012 & 16.76543 & 78.46156 \\
\hline 3 & 0.417022 & 5.017824 & 21.65469 & 73.32749 \\
\hline 4 & 0.418579 & 5.090205 & 21.86780 & 73.04200 \\
\hline 5 & 0.421647 & 5.074383 & 22.90540 & 72.02022 \\
\hline 6 & 0.422853 & 5.114346 & 23.26047 & 71.62519 \\
\hline 7 & 0.423987 & 5.191571 & 23.55496 & 71.25347 \\
\hline 8 & 0.424943 & 5.293553 & 23.76183 & 70.94461 \\
\hline 9 & 0.425820 & 5.414386 & 23.91891 & 70.66670 \\
\hline 10 & 0.426626 & 5.549909 & 24.03545 & 70.41464 \\
\hline
\end{tabular}

Source: computed by author using EViews software

An assessment of the variance decomposition of LRNPE in Table 1.4.4.5.III shows that a large amount of the variations witnessed by LRNPE is attributed to its own shock ranging between about $97.68 \%$ to $70.41 \%$ within the time horizons, but the shock faded out gradually towards the end of the horizon. The contribution of LRGDP and LRPE follows an increasing trend until the end of the period where it stood at about 5.54\% and $24.03 \%$ respectively

\subsubsection{Impulse Response Function}

The Impulse response function is shock to a VAR system. This function identifies the responsiveness of the dependent variables in the VAR when a shock is to put to the error term. A unit shock is applied to each variable and to its effects on VAR system. Impulse response function is discussed in figure 1.4.4.6.I.

Figure 1.4.4.6.I shows the response of GDP to GDP, GDP to plan expenditure and GDP to non-plan expenditure. While it can be also seen that when one-unit shock occurs in LRGDP variable, the response of LRGDP variable is to increase until the end of period. It can be seen that when one-unit shock occurs in 
LRPE variable, the response of LRGDP variable is to increase until the 4th period. After the 4th period, it remains constant and positive until the end. When one-unit shock occurs in LRNPE (non-plan expenditure) variable, the response of LRGDP variable becomes 0 in the 1st period and then becomes negative until the end of the period.

Figure 1.4.4.6.I shows the response of LRPE to LRGDP, LRPE to LRPE and LRPE to LRNPE. It can be seen that when 1 unit shock occurs in LRGDP variable, the response of LRPE variable is to decrease until the 2nd period. After the 2nd period, it shows an increase until the end of the period. When 1 unit shock occurs in LRPE variable share, the response of LRPE variable to decrease until the end of period but remain positive. And when 1 unit shock occurs in LRNPE variable, a decrease occurs and become negative in (LRPE) variable until the end of period.

Figure 1.4.4.6.I shows the response of LRNPE to LRGDP, LRNPE to LRPE and LRNPE to LRNPE. It can be seen that when 1 unit shock occurs in LRGDP variable, the response of LRNPE variable is to increase until the 2nd period. After the 2nd period, it starts to decrease and become near to 0 but remains positive until the end of the period. When 1 unit shock occurs in LRPE (plan expenditure) variable share, the response of LRNPE variable is to decrease until end of 2 nd period then start to increase in the beginning until the end of the period. When 1 unit shock occurs in LRNPE variable share, a sharp decrease occurs in non-plan expenditure (LRNPE) variable until the end of the 2 nd period, then its values becomes almost 0 from the beginning of the $3 r d$ period until the end of the period.

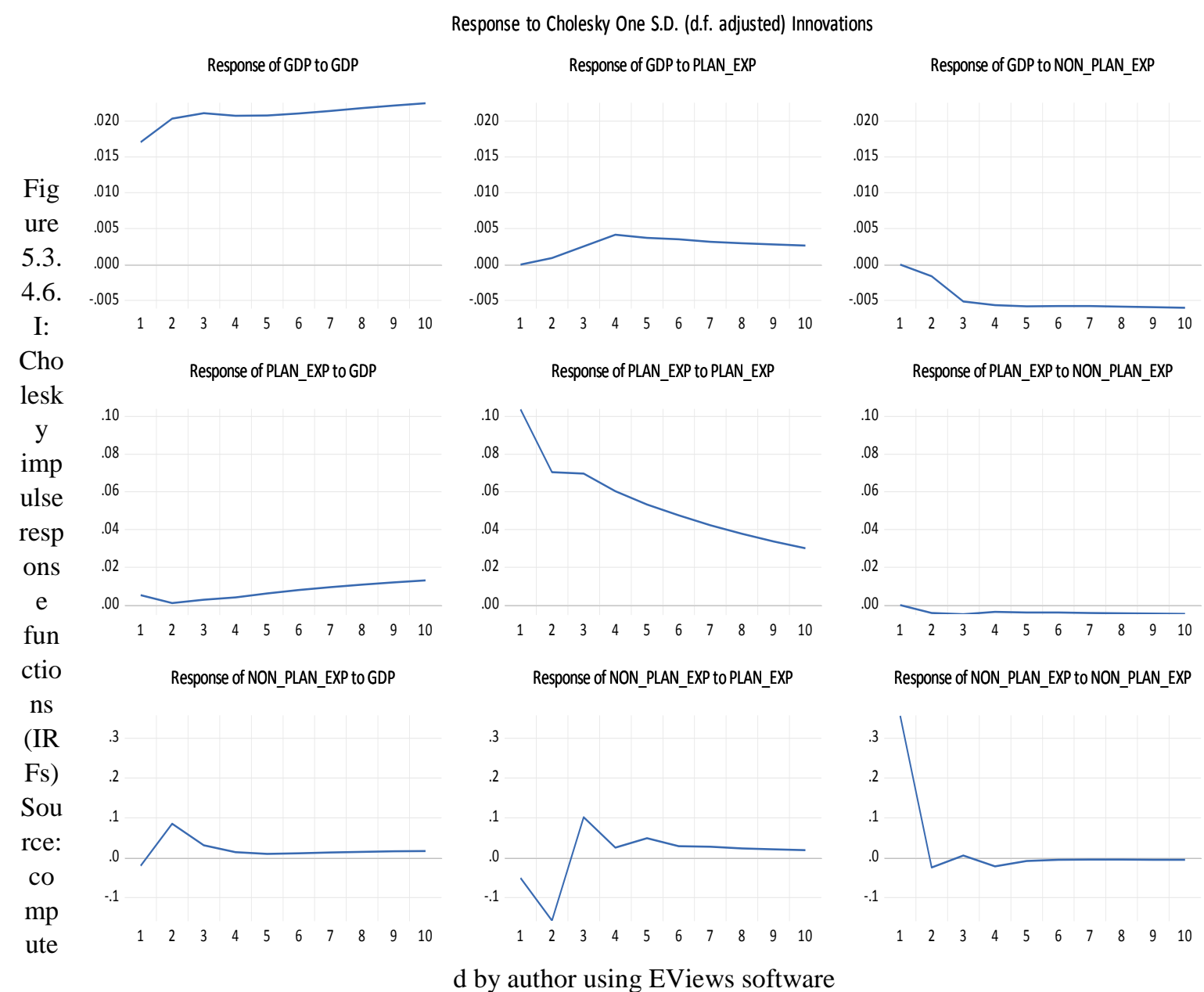

d by author using EViews software 


\section{Conclusion}

The objective of the paper is to investigate the causality relationship between plan expenditure and nonplan expenditure and economic growth. We used the Johansen-Juselius cointegration method to detect a long-term relationship between public expenditure and economic growth and use a unit root test for stationarity. The stationarity test concludes that all variables are stationary at first difference. The results of the cointegration test reveal an absence of a long-run relationship among the stationary variables. The results of the Granger causality tests suggest that there is a causal link between economic growth and non-plan expenditure and plan expenditure to non-plan expenditure which supports Wagner's hypothesis in India for the time period used under study.

The results of the Forecast Error Variance Decompositions test indicate that innovations in the variables are mostly explained by their own shocks. The impulse responses of the growth rate of Real Gross Domestic Product, plan expenditure and non-plan expenditure with respect to identified shocks (innovations) are consistent with the results of Variance Decomposition Analysis.

Non-plan expenditure comprises $90 \%$ of interest payments, subsidies defense expenditure and administrative payments which are non-developmental in nature and do not create any assets in future. Hence, the Indian government should monitor and scrutinize the non-developmental expenditure in nature and place further emphasis on this which should be developmental in its effect. It can be also concluded that non-plan expenditures are related to growth in Indian economy, so the results suggest that, in order to ensure growth of Indian economy, controlled increases in non-plan expenditure should be realized.

\section{References}

Acaravci, A., \& Özturk, İ. (2012). Foreign direct investment, export and economıc growth: empirical evidence from new eu countries. https://hdl.handle.net/20.500.12507/620

Olabisi, A. S., \& Oloni, E. F. (2012). Composition of public expenditure and economic growth in Nigeria. Journal of Emerging Trends in Economics and Management Sciences, 3(4), 403-407. https://journals.co.za/content/sl_jetems/3/4/EJC126566

Afxentiou, P. C. A.(1998)."Modeling the Relationship between Output and Goverment Expenditure in Canada". Keio Economic Studies, 17-43. https://core.ac.uk/download/pdf/145721733.pdf

Afzal, M. (2006). Causality between exports, world income and economic growth in Pakistan. International Economic Journal, 20(1), 63-77. https://doi.org/10.1080/10168730500515399

Agénor, P. R., \& Neanidis, K. C. (2011). The allocation of public expenditure and economic growth. The Manchester School, 79(4), 899-931. https://doi.org/10.1111/j.1467-9957.2011.02197.x

Banerjee, A., Dolado, J. J., Galbraith, J. W., \& Hendry, D. (1993). Co-integration, error correction, and the econometric analysis of non-stationary data. OUP Catalogue. https://ideas.repec.org/b/oxp/obooks/9780198288107.html

Barnes, B. J. (2008). A Cointegrating approach to budget deficits and long-term interest rates. Applied Economics, 40(2), 127-133. https://doi.org/10.1080/00036840600749722

Barrios, S., \& Schaechter, A. (2008). The quality of public finances and economic growth (No. 337). Directorate General Economic and Financial Affairs (DG ECFIN), European Commission. https://ideas.repec.org/p/euf/ecopap/0337.html

Barro, R. J. (1990). Government spending in a simple model of endogeneous growth. Journal of political economy, 98(5, Part 2), S103-S125.

Barro, R. J. (1991). Economic growth in a cross section of countries. The quarterly journal of economics, 106(2), 407443. https://doi.org/10.2307/2937943

Barro, R. J., \& Sala-i-Martin, X. (1992). Public finance in models of economic growth. The Review of Economic Studies, 59(4), 645-661. https://doi.org/10.2307/2297991 
Dickey, D. A., \& Fuller, W. A. (1979). Distribution of the estimators for autoregressive time series with a unit root. Journal of the American statistical association, 74(366a), 427-431. https://doi.org/10.1080/01621459.1979.10482531 Ebaidalla, E. M. (2013). Causality between government expenditure and national income: Evidence from Sudan. Journal of Economic Cooperation \& $\quad$ Development, 61 34(4), https://www.researchgate.net/profile/Ebaidalla_Ebaidalla/publication/283504103_Causality_between_Government_Ex penditure_and_National_Income_Evidence_from_Sudan/links/563c248108ae34e98c47e3f9.pdf

Engle, R. F., \& Granger, C. W. (1987). Co-integration and error correction: representation, estimation, and testing. Econometrica: journal of the Econometric Society, 251-276. https://www.jstor.org/stable/1913236?seq=1

Garba, T., \& Abdullahi, S. U. Y. U. (2013). Public Expenditure and Economic Growth: An Application of Cointegration and Granger Causality Tests on Nigeria. Journal of Economic \& Social Research, 15(1). https://search.proquest.com/docview/1641647111?pq-origsite=gscholar\&fromopenview=true

Ghartey, E. E. (2010). Cointegration and causal relationship between taxes and spending for Kenya, Nigeria and South Africa. International Economic Journal, 24(2), 267-282. https://doi.org/10.1080/10168730903510674

Goffman, I. J. (1968). Empirical Testing Of Wagners Law-Technical Note. Public Finance-Finances Publiques, 23(3), 359-366.

Egbetunde, T., \& O Fasanya, I. (2013). Public expenditure and economic growth in nigeria: Evidence from autoregressive distributed lag specifi cation. Zagreb international review of economics \& business, 16(1), 79-92. https://www.journalair.com/index.php/AIR/article/view/30128

Engle, R., \& Granger, C. (1991). Long-run economic relationships: Readings in cointegration. Oxford University Press. https://econpapers.repec.org/bookchap/oxpobooks/9780198283393.htm

Ginsburg, T. (2000). Does law matter for economic development? Evidence from East Asia. https://www.jstor.org/stable/3115145?seq=1

Gradstein, M. (2004). Governance and growth. Journal of Development Economics, 73(2), 505-518. https://doi.org/10.1016/j.jdeveco.2003.05.002

Granger, C. W. (1969). Investigating causal relations by econometric models and cross-spectral methods. Econometrica: journal of the Econometric Society, 424-438. https://www.jstor.org/stable/1912791

Granger, C. W. J. (2001). Developments in the study of cointegrated economic variables. Econometric Society Monographs, 33, 173-188. https://dl.acm.org/doi/abs/10.5555/781840.781850

Guilkey, D. K., \& Salemi, M. K. (1982). Small sample properties of three tests for Granger-causal ordering in a bivariate stochastic system. The Review of Economics and Statistics, 668-680. https://www.jstor.org/stable/1923951?seq=1

Nasiru, I. (2012). Government expenditure and economic growth in Nigeria: Cointegration analysis and causality testing. Academic Research International, 2(3), 718. http://www.savap.org.pk/journals/ARInt./Vol. 2(3)/2012(2.388).pdf

Johansen, S. (1988). Statistical analysis of cointegration vectors. Journal of economic dynamics and control, 12(2-3), 231-254. https://doi.org/10.1016/0165-1889(88)90041-3

Joharji, G. A., \& Starr, M. A. (2011). Fiscal policy and growth in Saudi Arabia. Review of Middle East Economics and Finance, 6(3), 24-45. https://doi.org/10.2202/1475-3693.1305

Kneller, R. (1999). Public expenditure and economic growth: A disaggregated analysis. Journal of Public economics, 73, 170-200.

Konya, L. (2004). Unit-root, cointegration and Granger causality test results for export and growth in OECD countries. International Journal of applied econometrics and quantitative studies, 1(2), 67-94. https://econpapers.repec.org/article/eaaijaeqs/v_3a1_3ay2004_3ai_3a1_5f10.htm

Landau, D. (1986). Government and economic growth in the less developed countries: an empirical study for 19601980. Economic Development and Cultural Change, 35(1), https://www.journals.uchicago.edu/doi/abs/10.1086/451572?journalCode=edcc

Liu, L. C. H., Hsu, C. E., \& Younis, M. Z. (2008). The association between government expenditure and economic growth: Granger causality test of US data, 1947-2002. Journal of Public Budgeting, Accounting \& Financial Management, 20(4), 537. http://citeseerx.ist.psu.edu/viewdoc/download?doi=10.1.1.1002.7399\&rep=rep1\&type=pdf Sevitenyi, L. N. (2012). Government expenditure and economic growth in Nigeria: An empirical investigation (1961 2009). The Journal of Economic Analysis, 3(1), 38-51. 
Masih, R., \& Masih, A. M. (1996). Macroeconomic activity dynamics and Granger causality: New evidence from a small developing economy based on a vector error-correction modelling analysis. Economic Modelling, 13(3), 407-426. https://doi.org/10.1016/0264-9993(96)01013-9

Ahmad, M. (2014). Government expenditure and economic growth: An econometric test for India. International Journal of Social Science and Humanities Research, 2(3), 79-88.

Dada, M. A., \& Adewale, O. A. (2013). Is Wagner's law a myth or a reality? Empirical evidence from Nigeria. International Journal of Development and Economic Sustainability, 1(1), 123-137.

Mehmood, R., \& Sadiq, S. (2010). The relationship between government expenditure and poverty: a cointegration analysis. Romanian Journal of Fiscal Policy (RJFP), 1(1), 29-37. https://www.econstor.eu/handle/10419/59799

Modebe, N. J., Okafor, R. G., Onwumere, J. U. J., \& Ibe, I. G. (2012). Impact of recurrent and capital expenditure on Nigeria's economic growth. European Journal of Business and Management, 4(19), 66-74. https://www.researchgate.net/publication/309346723_Impact_of_Recurrent_and_Capital_Expenditure_on_Nigeria's_Ec onomic_Growth

Lahirushan, K. P. K. S., \& Gunasekara, W. G. V. (2015). The impact of government expenditure on economic growth: A study of Asian countries. International Journal of Social, Behavioural, Educational, Economic, Business and $\begin{array}{llr}\text { Industrial } \quad \text { Engineering, } & \text { 9(9), 2995-3003. }\end{array}$ https://pdfs.semanticscholar.org/c92c/f5df9ee076cecb4193e6a63a1e04ebc98141.pdf

Payne, J. E., \& Ewing, B. T. (1996). International evidence on Wagner's hypothesis: A cointegration analysis. Public Finance $=$ Finances publiques, 51(2), 258-274. https://ideas.repec.org/a/pfi/pubfin/v51y1996i2p258-74.html

Pesaran, M. H., \& Shin, Y. (1998). An autoregressive distributed-lag modelling approach to cointegration analysis. $\begin{array}{llll}\text { Econometric } \quad \text { Society } & \text { Monographs, } & 31, & \end{array}$ http://citeseerx.ist.psu.edu/viewdoc/download?doi=10.1.1.153.3246\&rep=rep1\&type=pdf

Qasim, A. W., Kemal, M. A., \& Siddique, O. (2015). 4 Fiscal Consolidation and Economic Growth: A Case Study of Pakistan. https://www.pide.org.pk/ pideorgp/pdf/Working\%20Paper/WorkingPaper-124.pdf

Ram, R. (1987). Wagner's hypothesis in time-series and cross-section perspectives: Evidence from" real" data for 115 countries. The review of Economics and Statistics, 194-204. https://www.jstor.org/stable/1927226?seq=1

Ramayandi, A. (2003, July). Economic growth and government size in Indonesia: some lessons for the local authorities. In The 5th IRSA International Conference, Regional Development in the Era of Decentralization: Growth, Poverty, and Environment, Bandung. http://ceds.feb.unpad.ac.id/wopeds/200302.pdf

Dash, R. K., \& Sharma, C. (2008). Government expenditure and economic growth: Evidence from India. The IUP Journal of Public Finance, 6(3), 60-69. https://ideas.repec.org/a/icf/icfjpf/v06y2008i3p60-69.html

Roux, A. D. (1994). Defence, human capital and economic development in South Africa. African Defence Review, (19). https://www.africabib.org/s/rec.php?RID=P00049259

Weber, R., \& Singh, R. (1997). The composition of public expenditure and economic growth: can anything be learned from Swiss data? Swiss journal of economics and statistics. https://papers.ssrn.com/sol3/papers.cfm?abstract_id=1479816

Solow, R. M. (1956). A contribution to the theory of economic growth. The quarterly journal of economics, 70(1), 6594. https://doi.org/10.2307/1884513

Szarowská, I. (2014). Relationship between government spending and economic growth in the Czech Republic. Acta Universitatis Agriculturae Et Silviculturae Mendelianae Brunensis, 59 (7), 415-422. https://acta.mendelu.cz/59/7/0415/

Udah, B. (2010). Macroeconomic reforms, government size, an investment behavior in Nigeria: an empirical investigation. $\mathrm{J} \quad$ Sustain Dev Afr, $\quad 12(1), \quad 258-280 . \quad$ http://www.jsdafrica.com/Jsda/V12NO1_Spring2010_A/PDF/Macroeconomic\%20Reforms,\%20Government\%20Size,\%20and\%20Inv estment\%20Behavior\%20in\%20Nigeria\%20(Udah).pdf

Udoh, E. (2011). An examination of public expenditure, private investment and agricultural sector growth in Nigeria: Bounds testing approach. International Journal of Business and Social Science, 2(13), $285-292$. https://ijbssnet.com/journals/Vol._2_No._13_Special_Issue_July_2011/34.pdf

Visaria, P., \& Gumber, A. (1994). Utilisation of and expenditure on health care in India, 1986-87. Gujarat Institute of Development Research, Gota, Gujarat, 26-37.

Wang, Q., \& Wang, W. (2014). An analysis of Chinese government expenditure using dynamic binary panel data. Applied Economics, 46(11), 1259-1266. https://doi.org/10.1080/00036846.2013.870655 